\title{
SERVICE QUALITY ANALYSIS OF ARGO PARAHYANGAN TRAIN AS A TOOL FOR IMPROVING THE SERVICE
}

\author{
Rorim Panday \\ Pakuan University, Bogor, Indonesia , Indripan@yahoo.co.id
}

\begin{abstract}
Argo Parahyangan train is executive train for Jakarta-Bandung route, can be reached in 3 hours, with comfortable sitting in air condition compartment. This train becomes a favorite by executives. But the service of Argo Parahyangan is through decrease in quality of service. It can be known, because heard many complain about the service. This research is done by related to the variables of service quality at the train. Services quality cover three area that are service at ticket window, service at station and service in compartment. 18 variables have just identified. By 100 respondents's passenger as randomly, it got data using questionnaire. The opinion related to level of importance variables and level of service quality variables. In analyzing the data used multi variate method and descriptive analysis. The result as follow : (1) The quality of service is in range badly to good enough, (2)The quality of service is not meet the passenger expectation, (3) The level of passenger satisfaction (average ) is 70,90\%, and (4) Only 4 variables that significant influence to level of satisfaction, are : X1 - Accurateness of time travel, X3 - Service at ticket window, X11- Temperature in compartment, X12- Cleanness in compartment.
\end{abstract}

Keyword: service quality,level of satisfaction, multivariate,

\section{RESEARCH BACKGROUND}

Train transportation services have ever been loss its popularity in Indonesian transportation. This is related with the services which is still fall behind if we are compared to another transportation services. Schedule not on time, poor services, maintenance of facilities is not properly, etc. So, those variables impact to the people using train transportation, particularly for the middle class to up reluctant use the train transportation.

The most reluctance related with the facilities that should be exist, in a good condition, nevertheless in reality still in dissatisfaction condition, as example: dirty station, dirty toilet because there is no water or tissue, full trash and it does not empty, slow ticket services, waiter were not friendly and less attention to passenger.

Right now, government, which is representative by transportation ministry, began to pay attention at the transportation system. This is conducted with the effort to create efficiency in the mass transportation facility. Besides that, planned some efforts to reduce the dependency to another transportation mode, and make train transportation will be once sector that profitable, although actually the basic mission is give service facilities to the people.

This time, train transportation services are served by PT.Kereta Api Indonesia (Indonesia Train Limited Company), cover Jawa and Sumatera islands. 
Argo Parahyangan train, in the fact it have some competitors in transportation services from another transportation services like Bus Patas, Taxi 4848 and Travel minibus. Bus Patas is the bus with fast travelling for executives, Taxi 4848 is the fast taxi for Jakarta-Bandung route. Those competitors of Parahyangan train are the alternative transportation for people travelling to Bandung, particularly for the middle class to up, where they are use the executive class.

The competition condition forces the train transportation like Argo Parahyangan to improve their services for increasing more people using the train. To become attractive, although Argo Parahyangan train is created only for the people that want comfortability, amiability, cool, and prime services, in reality there are many sounds complaint from the passenger. The kinds of complaint are:

- The compartment were not cool

- The slow service on the train

- Water closed is not functioning properly

- Water closed were dirty, nothing water or tissue

- The television is not functioning properly

- Noise

- Etc

Complaints not only on the train. It is also at the station (departure and arrival) and at the ticketing. Based on that experience of complaints, it is a duty for the PT.KAI management to hear complaints and to know what kind of the complaint, with the aim for improving the services.

In reality there are many complaints about services. For those reason this research will be done. The problem for this research can be formulated as follows:

1. What kind the passenger of Argo Parahyangan train?

2. What kind the variables services which the passenger still complaint at Argo Parahyangan train?

3. What is the level of services quality in Argo Parahyangan train?

4. What is the level of satisfaction of passenger Argo Parahyangan train?

5. Is there relationship between level services quality and the level of satisfaction of the Argo Parahyangan passenger?

6. How the relationship between level services quality and the level of satisfaction of the Argo Parahyangan passenger?

The objectives of this research are:

1. To find out the kind of Argo Parahyangan Passenger

2. To find out the kind of services quality variables which is still complaint

3. To find out the level of services quality of Argo Parahyangan train

4. To find out the level of satisfaction of Argo Parahyangan Passenger

5. To find out the relationship between level of services quality and level of satisfaction

6. To find out the magnitude of the relationship between level of services quality and level of satisfaction

7. Determine the appropriate action and strategy for improving the services. 
The significances of this study are:

1. For improving the service of the PT.KAI, especially for Argo Parahyangan train.

2. As a monitoring the level of services quality and the level of satisfaction.

Scopes the research are limited as follows:

1. The research will be done at Argo Parahyangan train

2. Measure the preference or opinion of Argo Parahyangan passenger to the services quality and their satisfaction to the services.

3. This research is only one time shoot.

4. This research is only one trip for Bandung Jakarta passenger.

There are hypothesized that:

1. Services quality at Argo Parahyangan train is very good.

2. Service qualities at Argo Parahyangan have met the expectation of Argo Parahyangan passenger.

3. Passenger satisfaction is high

4. Service quality influence to passenger satisfaction.

The assumptions are used in this case:

1. This research only for Argo Parahyangan

2. The respondent have knowledge about services quality at Argo Parahyangan

3. The respondent have used Argo Parahyangan transportation more than one times

4. PT.KAI has been given the services at Argo Parahyangan in line with the plan.

5. Response of the respondent is independent

\section{LITERATURE REVIEW}

Quality of service will be associated with the products on offer, especially in the form of services. In this paper are train services. Railway services were strongly associated with the type of service performed or offered. The benefit of service cannot be seen, and will not produce ownership for anybody. There are four element of service; intangibility, inconsistency, inseparability and inventory (Berkowitz). While Kotler give the element as inconsistency, and inventory as variability and perishability.

Service to serve consumer behavior.The consumer behavior is the action of someone for buying or using the goods or service, including in decision process. The decision to buy include product choice, brand, agent, time of buying and number of buying. The decision to buy depends on the buyer's black box in the stimulation by several things such as stimulation from information of produc and macro environment of the buyer. The marketing task is to understand what happen in the buyer's black box between outside stimulation and buying decision of the buyer. Before buying decision, the buyer will pass through 3 phase in buying process: problem identification, searching of the information, and alternative evaluation (Kotler). 
In the behavior of traveling the emphasize is at the choice process. In choice behavior transportation service is the evaluation each alternative on the main attributes. Manheim (1979) formulated there are 5 attribute in transportation, as follow:

1. Time attribute

- Total time travelling

- Variance of travelling time/ accuracy of travelling

- Transfer time

- Travelling frequency

2. Cost attribute

- Direct cost of transportation

- Indirect cost of transportation

- Additional cost

3. Security attribute

- Safety of the passenger

- Safety of baggage

- Safety from crime

- Safety tools.

4. Comfortable and convenient attribute

- Physic comfortable (temperature, humidity, cleanness etc)

- Psychology comfortable (status, privacy)

- Hospitality of stewardess

- Accessibility to departure

- Accessibility to destination

5. Expedition services

- Assurance

- Right of return

Before decision to buy, customer estimate which offer will deliver the most value, within the bounds of search costs and limited knowledge, mobility, and income. Buyers will buy from the firm that they perceive to offer the highest customer delivered value. Customer delivered value is the difference between total customer value and total customer cost. And total customer value is the bundle of benefits customers expect from a given product or service. The total customer cost consists of more than the monetary cost. Thus, we assert that the buyer forms a judgment of value and acts on it. Whether the buyer is satisfied after purchase depends upon the offer's performance in relation to the buyer's expectations.

Satisfaction is the level of a person's felt state resulting from comparing a product's perceived performance (or outcome) in relation to the person's expectations. Thus the satisfaction level is a function of the difference between perceived performance and expectations. A customer could experience one of three broad levels of satisfaction. If the performance falls short of expectations, the customer is dissatisfied. If the performance matches the expectations, the customer is satisfied. If the performance exceeds expectations, the customer is highly satisfied, pleased, or delighted. 
A company's tools for tracking and measuring customer satisfaction range from the primitive to the sophisticated. Companies use the following methods to measure how much customer satisfaction they are creating. A customer-centered organization would make it easy for its customers to deliver suggestions and complaints. Some provide forms for guests to report their likes and dislikes, place suggestion boxes in the corridors, supply comment cards to exiting patients, and hire a patient advocate to handle patient grievances, "customer hot lines". These information flows provide these companies with many good ideas and enable them to act more rapidly to resolve problems.

A company must not conclude that it can get a full picture of customer satisfaction and dissatisfaction by simply running a complaint and suggestion system. Companies can not use complaint levels as a measure of customer satisfaction. Responsive companies obtain a direct measure of customer satisfaction by conducting periodic surveys. They send questionnaires or make telephone calls to a random sample of their recent customers to find out how they feel about various aspects of the company's performance.

Relation to customer satisfaction, and quality of service on the railways, there are some researchers who have conducted research on the matter. Sheeba. A and K. Kumuthadevi (2013), research do on passenger (Customer) satisfaction of Indian railways and service quality. This study identifies factors of service quality of Indian Railways in the train. The study is exploratory in nature and used factor analysis to identify the most and least important factors of customer satisfaction on service quality. The research methodology is empirical, and a survey of passengers (customers) was conducted. This study considered seven factors and 16 variables to analyze the passenger satisfaction. The study analyzed reliability Coefficient, Eigen Value and components Correlation Matrix etc. The findings of this study reveals that the most important factors determining satisfaction of passengers in train are serially comes as basic facilities, hygiene, safety \& security, catering, health care service, punctuality, behavior towards passengers.

Syed Muhammad Irfan, Daisy Mui Hung Kee and Saman Shahbaz (2012) do research of service quality and rail transportation in Pakistan. They research aims to investigate the passengers' perceptions about the service quality of rail transport system in Pakistan while traveling between the major cities especially from Lahore to Karachi, Multan, Peshawar and Rawalpindi. A modified SERVQUAL instrument including eight service quality constructs: empathy, assurance, tangibles, timeliness, responsiveness, information system, food and safety and security were employed to measure the passengers" perceptions about the service quality of railways. Out of 700 respondents, only 493 were selected and these respondents were frequent railway traveler on these routes. Results indicate that passengers perceive that quality of services delivered to them is not satisfactory.

Khan Rubayet RAHAMAN and Md. Arifur RAHAMAN (2009), do research of service quality attributes affecting the satisfaction on railway passenger at selective route in southwestrn part of Bangladesh.This study has aimed to focus on the railway transportation sector and to develop a model defining the relationship between overall satisfaction and service quality attributes in a selective route from Khulnato Rajshahi in southwestern zone of Bangladesh so that it can reinforce further improvement process. Findings show that, overall service satisfaction depend on eight distinct service quality 
attributes. It implies the service with worst situation, overall satisfaction of service and need for priority improvement to support further orientation, addition and betterment of service to draw maximum economic and development benefit for those linking regions.

Abadi dwi Saputra (2010) do his research in Indonesia on analysis of train passenger responses on provided service. The objective of his research is to analyze the relationship between customer satisfaction towards provided service with the desire to do a complaint and to find the factor from service quality that has significant influences to customer satisfaction towards PT KAI services. He comparison study between PT Kereta Api Indonesia and Statens Järnvägar (SJ) AB, Sweden, he recommend the service standards design, service guarantee and complaint handling system that need to be adjusted with the interest of consumer. The data was collected via field survey in the station that located in Jakarta, Yogyakarta and Pekalongan. This research shows several findings. First,there are six factors of service quality attributes that have significant influences to customer satisfaction towards PT KAI services for commuter class (Information, Appearances, Service coverage, Tangible, Safety \& security, and Cost), seven factors for business class (Travel time,Information, Scheduling, Comfort, Tangible, Safety \& security, and Service coverage), and also seven factor for executive class (Appearances, Safety \& security, Information, Comfort, Tangible, Travel time, and Cost). Second, while the commuter class passengers complain on the Safety \& security attribute, for business class it is the information that influence the desire to complain. Meanwhile for executive class, passengers are mostly satisfied with the service given by PT KAI.Third, to decrease the number of complaints, some effective mechanisms to handle those complaints and learning from Statens Järnvägar (SJ) AB are necessary to take. Fourth, theservice standards for PT KAI can be classified into 6 details of service,(safety and security attributes; comfort and appearances attributes; availability of information aspect attributes; tangible attributes; service coverage attributes; and the operations of train). For service guarantee design, this research focus on travel time guarantee. Learning from Statens Järnvägar (SJ) AB on Sweden service guarantee, PT KAI can adopt and use their system to increase customer satisfaction .

Based on the above four researchers, the research to be conducted with regard to the level of satisfaction and service quality railway users.

\section{RESEARCH METHODS}

To implement the research, the service variables are determined. These variables are determined based on experience and literature, which represent the service quality. Respondents were asked to:

- Rate the importance of these variables level and the service quality variables level.

- Determine the level of their satisfaction

- Provide their self information such as: occupation, education, income per month, Frequency of travelling by Argo Parahyangan, using another transportation mode and the objective of travelling by Argo Parahyangan.

After that the quantitative approaches which are capable of analyzing the multi variables will be utilized. 
The research designed to generate and analyze information for several variables which represent the service quality variables.

These variables are:

1. X1- Accurateness of time travel

2. X2- Frequency of Argo Parahyangan in a day

3. X3- Service at ticket counter

4. X4- Fastness of service at ticket counter

5. X5- Security at station

6. X6- Service at waiting room

7. X7- Comfortable at sitting in compartment

8. X8- To handle shock problem

9. X9- To handle the noise

10. X-10 Comfortable of compartment condition

11. X-11Temperature in Compartment / AC

12. X12- Cleanness in compartment

13. X13- Fastness of service in compartment

14. X14- Entertainment facilities/TV/ music in compartment

15. X15- Cleanness of water closed in compartment

16. X16- Security in compartment

17. X17- Menu in compartment

18. X-18 Expense

The lickert scale from 1 to 5 used in the questionnaires. Questionnaire consisted of three part. The first part is about passenger identity. At the second and the third questionnaires passenger should be rating the lickert scale. Gradation of the level of importance of service variables, which describing the passenger expectations of service quality are as follows:

1- Not important

2 - Less important

3 - important enough

4 - Important

5 - Very importance

Gradation of the level of quality of service variables are as follows:

$$
\begin{aligned}
& 1 \text { - Worst } \\
& 2 \text { - Badly } \\
& 3 \text { - Good enough } \\
& 4 \text { - good } \\
& 5 \text { - Very good }
\end{aligned}
$$

The questionnaire designed as match as possible with the goals of the research. As respondents were passengers of Argo Parahyangan train, Bandung -Jakarta route using random sampling method. Number of compartment for Argo Parahyangan for one trip is consist of 5 compartment for passenger, one compartment for restaurant, one compartment for diesel energy, and the locomotive. In each compartment consist of 50 passengers. If the seat is full, there are 250 passenger for one trip. For this research 
determined each compartment 25 respondent. Thus, there are a total of 125 respondents planned. Data processed using SPSS version 11.0, under windows program. Data processed by multi variate method and uni variate method such as factor and multiple regression method. Whereas the uni-variate method will be processed by use t-test.

\section{RESULT AND DISCUSSIONS}

In this research, from target 125 respondents, the properly answer the questionnaire are 100 respondents. The respondent information are shown in table-1

Table 1. Respondent description

\begin{tabular}{|c|c|c|c|c|c|}
\hline Occupation & Businessman & $\begin{array}{c}\text { State } \\
\text { Employee }\end{array}$ & Student & $\begin{array}{c}\text { Private } \\
\text { employee }\end{array}$ & Another \\
\hline & $17 \%$ & $25 \%$ & $11 \%$ & $35 \%$ & $12 \%$ \\
\hline \multirow[t]{2}{*}{ Education } & SMTA & Bsc & S1 & S2 & S3 \\
\hline & $15 \%$ & $23 \%$ & $33 \%$ & $26 \%$ & $3 \%$ \\
\hline \multirow[t]{2}{*}{ Income/month } & $<500.000 \mathrm{IDR}$ & $\begin{array}{c}500.000- \\
1.000 .000 \mathrm{IDR}\end{array}$ & $\begin{array}{c}1.000 .000- \\
1.500 .000 \mathrm{IDR}\end{array}$ & $\begin{array}{c}1.500 .000- \\
2.000 .000 \mathrm{IDR}\end{array}$ & $\begin{array}{c}>2.000 .000 \\
\text { IDR }\end{array}$ \\
\hline & $1 \%$ & $15 \%$ & $11 \%$ & $14 \%$ & $59 \%$ \\
\hline \multirow[t]{2}{*}{$\begin{array}{l}\text { Frequency use } \\
\text { Argo } \\
\text { Parahyangan }\end{array}$} & $1-5$ times & 5-10 times & 10-15 times & & \\
\hline & $91 \%$ & $8 \%$ & $1 \%$ & & \\
\hline \multirow[t]{2}{*}{$\begin{array}{l}\text { Another } \\
\text { transportation }\end{array}$} & Private vehicle & $\begin{array}{l}\text { Parahyangan } \\
\text { executive }\end{array}$ & Bus Patas & Taxi & \\
\hline & $29 \%$ & $56 \%$ & $11 \%$ & $4 \%$ & \\
\hline \multirow[t]{2}{*}{$\begin{array}{l}\text { Travelling } \\
\text { purpose }\end{array}$} & Business & Office duty & Picnic & $\begin{array}{l}\text { Another } \\
\text { purpose }\end{array}$ & \\
\hline & $22 \%$ & $31 \%$ & $8 \%$ & $39 \%$ & \\
\hline
\end{tabular}

Referred to the table 1, based on occupation, that is $17 \%$ of respondent are businessmen , $25 \%$ of respondent are state employee / TNI (Indonesian National Army), $11 \%$ of respondent are students, $35 \%$ of respondents are private employee, and $12 \%$ of respondent are another.

In respondent last education, that is $15 \%$ of respondent are SMTA ( Senior High School), 23\% of respondent are Bachelor of Art, 33\% of respondent are S1, $26 \%$ of respondent are Masters (S2), and 3\% of respondent are Doctoral (S3).

Respondent income/ month, that $1 \%$ of respondent has total income per month $<500$ thousand, $15 \%$ of respondent have total income per month from 750 thousand to 1 million rupiah's , $11 \%$ of respondent have total income per month 1 million to 1,5 million rupiahs, $14 \%$ of respondent have total income 1,5 million to 2 million rupiah, and $59 \%$ of respondent have total income greater than 2 million rupiah.

Frequency use the train by respondent, that $91 \%$ respondent using the Argo Parahyangan 1-5 times a month, $8 \%$ of respondent using the Argo Parahyangan 5- 10 times a month and $1 \%$ of respondent using the Argo Parahyangan 10-15 times a month.

On another transportation usage by respondent, that $29 \%$ of respondent using private vehicle, $56 \%$ of respondent using Argo Parahyangan Executive train , and $11 \%$ of respondent using Bus Pattas, $4 \%$ of respondent using taxi.

On travelling purpose by respondent, that $22 \%$ of respondent have aim for business, $31 \%$ of respondent have aim for office task, $8 \%$ of respondent for picnic and 39 $\%$ of respondent for another aim. 


\section{Response Analysis for Level of Importance Variable and level of Service quality}

Table-2 describe the frequency of response for important variables and service quality variables.

Table 2.Frequency of respondent to variables

\begin{tabular}{|c|c|c|c|c|c|c|c|c|c|c|c|c|}
\hline & \multicolumn{9}{|c|}{ Important variable } & \multicolumn{6}{|c|}{ Service quality } & \\
\hline & 1 & 2 & 3 & 4 & 5 & $\begin{array}{c}\text { Averags } \\
\text { value }\end{array}$ & 1 & 2 & 3 & 4 & 5 & $\begin{array}{c}\text { Averags } \\
\text { value }\end{array}$ \\
\hline & \multicolumn{9}{|c|}{ Frequency } & & & \multicolumn{7}{|c|}{ Frequency } & & \\
\hline X1 & & & & 21 & 79 & 4,79 & 1 & 6 & 29 & 44 & 20 & 3,76 \\
\hline X2 & & & 25 & 36 & 39 & 4,14 & 1 & 20 & 42 & 29 & 8 & 3,23 \\
\hline X3 & & & 9 & 39 & 52 & 4,43 & 1 & 3 & 52 & 38 & 6 & 3,45 \\
\hline X4 & & & 9 & 36 & 55 & 4,46 & 1 & 4 & 52 & 33 & 10 & 3,47 \\
\hline X5 & & & 10 & 22 & 68 & 4,58 & 3 & 11 & 48 & 27 & 11 & 3,32 \\
\hline X6 & 2 & & 29 & 42 & 27 & 3,92 & 3 & 16 & 53 & 24 & 4 & 3,1 \\
\hline X7 & & & 7 & 36 & 57 & 4,5 & 1 & 5 & 43 & 38 & 13 & 3,57 \\
\hline X8 & & 7 & 8 & 33 & 52 & 4,3 & 5 & 30 & 40 & 18 & 7 & 2,92 \\
\hline X9 & 2 & 3 & 12 & 31 & 52 & 4,28 & 3 & 25 & 38 & 28 & 6 & 3,09 \\
\hline X10 & & & 10 & 35 & 55 & 4,45 & 1 & 8 & 44 & 37 & 10 & 3,47 \\
\hline X11 & & 2 & 11 & 31 & 56 & 4,41 & & 12 & 41 & 35 & 12 & 3,47 \\
\hline X12 & & 2 & 4 & 28 & 66 & 4,58 & 3 & 5 & 46 & 35 & 11 & 3,46 \\
\hline X13 & & & 22 & 47 & 31 & 4,09 & 1 & 4 & 54 & 33 & 8 & 3,43 \\
\hline X14 & 2 & 10 & 39 & 26 & 23 & 3,58 & 5 & 40 & 34 & 18 & 3 & 2,74 \\
\hline X15 & 2 & 3 & 5 & 21 & 69 & 4,52 & 7 & 27 & 44 & 14 & 8 & 2,89 \\
\hline X16 & & 2 & 5 & 19 & 74 & 4,65 & & 7 & 49 & 30 & 14 & 3,51 \\
\hline X17 & & 4 & 30 & 48 & 18 & 3,8 & 2 & 13 & 54 & 27 & 4 & 3,18 \\
\hline X18 & & 10 & 22 & 48 & 20 & 3,78 & & 6 & 51 & 32 & 11 & 3,48 \\
\hline
\end{tabular}

Referred to table-2, decriptive to importance variables as follows:

Table-3 Descriptive analysis of importance Variables

\begin{tabular}{|l|l|}
\hline \multicolumn{1}{|c|}{ Varibles } & \multicolumn{1}{|c|}{ Explanation of Importance Variables } \\
\hline X1 variable - Accurateness of time travel & $\begin{array}{l}21 \% \text { of respondent consider that timeliness is } \\
\text { important. While 79\% of respondent consider that } \\
\text { variable very important. }\end{array}$ \\
\hline $\begin{array}{l}\text { X2 variable - Frequency of Argo Parahyangan in a } \\
\text { day }\end{array}$ & $\begin{array}{l}36 \% \text { of respondent consider as important, And 39 } \\
\% \text { of respondent consider as very important. }\end{array}$ \\
\hline X3 Variable - Service at ticket window & $\begin{array}{l}39 \% \text { of respondent consider as important, And 52 } \\
\% \text { of respondent gave consider as very important. }\end{array}$ \\
\hline X4 variable - Fastness of service at ticket window & $\begin{array}{l}936 \% \text { of respondent consider as important, and 55 } \\
\% \text { of respondent consider as very important. }\end{array}$ \\
\hline X5 variable - Security at station & $\begin{array}{l}22 \% \text { of respondent consider as important, And 68 } \\
\% \text { of respondent consider as very important. }\end{array}$ \\
\hline X6 variable - Service at waiting room & $\begin{array}{l}42 \% \text { of respondent gave consider as important. And } \\
27 \% \text { of respondent consider as very important }\end{array}$ \\
\hline X7 variable - Comfortable at sitting in compartment & $\begin{array}{l}36 \% \text { of respondent consider as as important, and 57 } \\
\% \text { of respondent consider as very important. }\end{array}$ \\
\hline X8 variable - To handle shock problem & $33 \%$ of respondent consider as important. And 52 \\
& $\begin{array}{l}\text { \% of respondent consider as very important } \\
\text { X9 variable - To handle the noise }\end{array}$ \\
\hline
\end{tabular}




\begin{tabular}{|c|c|}
\hline $\begin{array}{l}\text { X10 variable - comfortable of compartment } \\
\text { condition }\end{array}$ & $\begin{array}{l}35 \% \text { of respondent consider as important, And } 55 \\
\% \text { of respondent consider as very important. }\end{array}$ \\
\hline $\mathrm{X} 11$ variable - Temperature in compartment / AC & $\begin{array}{l}31 \% \text { of respondent consider as important. And } 56 \\
\% \text { of respondent consider as very important }\end{array}$ \\
\hline $\mathrm{X} 12$ variable - Cleanness in compartment & $\begin{array}{l}28 \% \text { of respondent consider as important. And } 66 \\
\% \text { of respondent consider as very important. }\end{array}$ \\
\hline $\mathrm{X} 13$ variable - Fastness of service in compartment & $\begin{array}{l}47 \% \text { of respondent consider as important, And } 31 \\
\% \text { of respondent consider as very important. }\end{array}$ \\
\hline $\begin{array}{l}\text { X14 variable - Entertainment facilities /TV/ music } \\
\text { in compartment }\end{array}$ & $\begin{array}{l}26 \% \text { of respondent consider as important. And } 23 \\
\% \text { of respondent consider as very important. }\end{array}$ \\
\hline $\begin{array}{l}\text { X15 variable - Cleanness of Water Closed in } \\
\text { compartment }\end{array}$ & $\begin{array}{l}21 \% \text { of respondent consider as important. And } 69 \\
\% \text { of respondent consider as very important. }\end{array}$ \\
\hline X16 variable - Security in compartment & $\begin{array}{l}19 \% \text { of respondent consider as important. And } 74 \\
\% \text { of respondent consider as very important. }\end{array}$ \\
\hline X17 variable - Menu in Compartment & $\begin{array}{l}48 \% \text { of respondent consider as important. And } 18 \\
\% \text { of respondent consider as very important }\end{array}$ \\
\hline X18 variable - Expense & $\begin{array}{l}48 \% \text { of respondent consider as important. And } 20 \\
\% \text { of respondent consider as very important }\end{array}$ \\
\hline
\end{tabular}

Referred to table-2, decriptive to quality of service variables as follows:

Table- 4 descriptive analysis of service quality variables

\begin{tabular}{|c|c|}
\hline Varibles & Explanation of Service quality Variables \\
\hline X1 variable - Accurateness of time travel & $\begin{array}{l}29 \% \text { of respondent consider as a good enough } \\
\text { quality of service, } 44 \% \text { of respondent consider as a } \\
\text { good quality of service , and } 20 \% \text { of respondent } \\
\text { consider as a very good quality of service }\end{array}$ \\
\hline $\begin{array}{l}\text { X2 variable - Frequency of Argo Parahyangan in a } \\
\text { day }\end{array}$ & $\begin{array}{l}42 \% \text { of respondent consider as a good enough } \\
\text { quality of service, } 29 \% \text { of respondent consider as a } \\
\text { good quality of service, and } 8 \% \text { of respondent } \\
\text { consider as a very good quality of service. }\end{array}$ \\
\hline X3 Variable - Service at ticket window & $\begin{array}{l}52 \% \text { of respondent consider as a good enough } \\
\text { quality of service, } 38 \% \text { of respondent consider as a } \\
\text { good quality of service, and } 6 \% \text { of respondent } \\
\text { consider as a very good quality of service. }\end{array}$ \\
\hline X4 variable - Fastness of service at ticket window & $\begin{array}{l}52 \% \text { of respondent consider as a good enough } \\
\text { quality of service, } 33 \% \text { of respondent consider as a } \\
\text { good quality of service, and } 10 \% \text { of respondent } \\
\text { consider as a very good quality of service }\end{array}$ \\
\hline X5 variable - Security at station & $\begin{array}{l}48 \% \text { of respondent consider as a good enough } \\
\text { quality of service, } 27 \% \text { of respondent consider as a } \\
\text { good quality of service, and } 11 \% \text { of respondent } \\
\text { consider as a very good quality of service. }\end{array}$ \\
\hline X6 variable - Service at waiting room & $\begin{array}{l}53 \% \text { of respondent consider as a good enough } \\
\text { quality of service, } 24 \% \text { of respondent consider as a } \\
\text { good quality of service, and } 4 \% \text { of respondent } \\
\text { consider as a very good quality of service }\end{array}$ \\
\hline $\mathrm{X} 7$ variable - Comfortable at sitting in compartment & $\begin{array}{l}43 \% \text { of respondent consider as a good enough } \\
\text { quality of service, } 38 \% \text { of respondent consider as a } \\
\text { good quality of service, and } 13 \% \text { of respondent } \\
\text { consider as a very good quality of service. }\end{array}$ \\
\hline
\end{tabular}




\begin{tabular}{|c|c|}
\hline X8 variable - To handle shock problem & $\begin{array}{l}40 \% \text { of respondent consider as a good enough } \\
\text { quality of service, } 18 \% \text { of respondent consider as a } \\
\text { good quality of service, and } 7 \% \text { of respondent } \\
\text { consider as a very good quality of service. }\end{array}$ \\
\hline X9 variable - To handle the noise & $\begin{array}{l}38 \% \text { of respondent consider as a good enough } \\
\text { quality of service, } 28 \% \text { of respondent consider as a } \\
\text { good quality of service, and } 6 \% \text { of respondent } \\
\text { consider as a very good quality of service. }\end{array}$ \\
\hline X10 variable - comfortable of compartment codition & $\begin{array}{l}44 \% \text { of respondent consider as a good enough } \\
\text { quality of service, } 37 \% \text { of respondent consider as a } \\
\text { good quality of service, and } 10 \% \text { of respondent } \\
\text { consider as a very good quality of service. }\end{array}$ \\
\hline $\mathrm{X} 11$ variable - Temperature in compartment / $\mathrm{AC}$ & $\begin{array}{l}41 \% \text { of respondent consider as a good enough } \\
\text { quality of service, } 35 \% \text { of respondent consider as a } \\
\text { good quality of service, and } 12 \% \text { of respondent } \\
\text { consider as a very good quality of service. }\end{array}$ \\
\hline $\mathrm{X} 12$ variable - Cleanness in compartment & $\begin{array}{l}46 \% \text { of respondent consider as a good enough } \\
\text { quality of service, } 35 \% \text { of respondent consider as a } \\
\text { good quality of service, and } 11 \% \text { of respondent } \\
\text { consider as a very good quality of service. }\end{array}$ \\
\hline X13 variable - Fastness of service in compartment & $\begin{array}{l}54 \% \text { of respondent consider as a good enough } \\
\text { quality of service, } 33 \% \text { of respondent consider as a } \\
\text { good quality of service, and } 8 \% \text { of respondent } \\
\text { consider as a very good quality of service. }\end{array}$ \\
\hline $\begin{array}{l}\text { X14 variable - Entertainment facilities /TV/ music } \\
\text { in compartment }\end{array}$ & $\begin{array}{l}34 \% \text { of respondent consider as a good enough } \\
\text { quality of service, } 18 \% \text { of respondent consider as a } \\
\text { good quality of service, and } 3 \% \text { of respondent } \\
\text { consider as a very good quality of service }\end{array}$ \\
\hline $\begin{array}{l}\text { X15 variable - Cleanness of Water Closed in } \\
\text { compartment }\end{array}$ & $\begin{array}{l}44 \% \text { of respondent consider as a good enough } \\
\text { quality of service, } 14 \% \text { of respondent consider as a } \\
\text { good quality of service, and } 8 \% \text { of respondent } \\
\text { consider as a very good quality of service. }\end{array}$ \\
\hline X16 variable - Security in compartment & $\begin{array}{l}49 \% \text { of respondent consider as a good enough } \\
\text { quality of service, } 30 \% \text { of respondent consider as a } \\
\text { good quality of service, and } 14 \% \text { of respondent } \\
\text { consider as a very good quality of service. }\end{array}$ \\
\hline X17 variable - Menu in Compartment & $\begin{array}{l}54 \% \text { of respondent consider as a good enough } \\
\text { quality of service, } 27 \% \text { of respondent consider as a } \\
\text { good quality of service, and } 4 \% \text { of respondent } \\
\text { consider as a very good quality of service. }\end{array}$ \\
\hline X18 variable - Expense & $\begin{array}{l}51 \% \text { of respondent consider as a good enough } \\
\text { quality of service, } 32 \% \text { of respondent as a good } \\
\text { quality of service, and } 11 \% \text { of respondent consider } \\
\text { as a very good quality of service. }\end{array}$ \\
\hline
\end{tabular}

Based on data in table-2, we see to the average value, it appears that the level of service quality has not met the expectations of passengers. In this case the expectation of passengers is greater than the quality of existing services. For that, there needs to be testing the expectation value with the value of quality of service, using t-test testing. The t-test results shown in table-5. 
Table-5.t test testing

\begin{tabular}{|c|c|c|c|c|c|}
\hline & & & & & \\
\hline & $\begin{array}{c}\text { Average } \\
\text { value of } \\
\text { important } \\
\text { level }\end{array}$ & $\begin{array}{c}\text { Averag } \\
\text { value of } \\
\text { Service } \\
\text { level }\end{array}$ & t- Table & t-computation & \\
\hline $\mathrm{X} 1$ & 4,79 & 3,76 & 1,645 & 10,609 & Ho rejected \\
\hline $\mathrm{X} 2$ & 4,14 & 3,23 & 1,645 & 7,605 & Ho rejected \\
\hline $\mathrm{X} 3$ & 4,43 & 3,45 & 1,645 & 10,207 & Ho rejected \\
\hline $\mathrm{X} 4$ & 4,46 & 3,47 & 1,645 & 9,765 & Ho rejected \\
\hline $\mathrm{X} 5$ & 4,58 & 3,32 & 1,645 & 11,076 & Ho rejected \\
\hline $\mathrm{X} 6$ & 3,92 & 3,1 & 1,645 & 6,887 & Ho rejected \\
\hline $\mathrm{X} 7$ & 4,5 & 3,57 & 1,645 & 9,009 & Ho rejected \\
\hline $\mathrm{X} 8$ & 4,3 & 2,92 & 1,645 & 10,399 & Ho rejected \\
\hline $\mathrm{X} 9$ & 4,28 & 3,09 & 1,645 & 8,967 & Ho rejected \\
\hline $\mathrm{X} 10$ & 4,45 & 3,47 & 1,645 & 9,228 & Ho rejected \\
\hline $\mathrm{X} 11$ & 4,41 & 3,47 & 1,645 & 8,169 & Ho rejected \\
\hline $\mathrm{X} 12$ & 4,58 & 3,46 & 1,645 & 10,207 & Ho rejected \\
\hline $\mathrm{X} 13$ & 4,09 & 3,43 & 1,645 & 6,357 & Ho rejected \\
\hline $\mathrm{X} 14$ & 3,58 & 2,74 & 1,645 & 6,135 & Ho rejected \\
\hline $\mathrm{X} 15$ & 4,52 & 2,89 & 1,645 & 12,199 & Ho rejected \\
\hline $\mathrm{X} 16$ & 4,65 & 3,51 & 1,645 & 10,730 & Ho rejected \\
\hline $\mathrm{X} 17$ & 3,8 & 3,18 & 1,645 & 5,614 & Ho rejected \\
\hline $\mathrm{X} 18$ & 3,78 & 3,48 & 1,645 & 2,558 & Ho rejected \\
\hline
\end{tabular}

As shown in Table-5, it is evident that the value of the variable expectations of service, is not equal to the value of quality of service. Tests were conducted at $5 \%$ level of confidence. Then, the question is which variables are most important to be considered by PT.KAI? For that, of course, need further statistical analysis, to see which variables are most important to be aware of. Furthermore, for data analysis, used factor analysis and multiple regression.

\section{Descriptive of level of satisfaction}

The level of respondent satisfaction can be expressed in percentage. The frequency of level satisfaction can be seen at the table below:

Table 6, Respondent frequency for level of satisfaction

\begin{tabular}{|c|c|c|c|c|c|}
\hline & & Frequency & Percent & $\begin{array}{l}\text { Valid } \\
\text { Percent }\end{array}$ & $\begin{array}{c}\text { Cumulat iv e } \\
\text { Percent }\end{array}$ \\
\hline \multirow[t]{17}{*}{ Valid } & 40 & 3 & 3.0 & 3.0 & 3.0 \\
\hline & 47 & 1 & 1.0 & 1.0 & 4.0 \\
\hline & 50 & 11 & 11.0 & 11.0 & 15.0 \\
\hline & 55 & 2 & 2.0 & 2.0 & 17.0 \\
\hline & 60 & 15 & 15.0 & 15.0 & 32.0 \\
\hline & 65 & 1 & 1.0 & 1.0 & 33.0 \\
\hline & 70 & 16 & 16.0 & 16.0 & 49.0 \\
\hline & 72 & 2 & 2.0 & 2.0 & 51.0 \\
\hline & 75 & 17 & 17.0 & 17.0 & 68.0 \\
\hline & 79 & 2 & 2.0 & 2.0 & 70.0 \\
\hline & 80 & 8 & 8.0 & 8.0 & 78.0 \\
\hline & 85 & 5 & 5.0 & 5.0 & 83.0 \\
\hline & 87 & 1 & 1.0 & 1.0 & 84.0 \\
\hline & 89 & 1 & 1.0 & 1.0 & 85.0 \\
\hline & 90 & 13 & 13.0 & 13.0 & 98.0 \\
\hline & 95 & 2 & 2.0 & 2.0 & 100.0 \\
\hline & Total & 100 & 100.0 & 100.0 & \\
\hline Total & & 100 & 100.0 & & \\
\hline
\end{tabular}


From the table, it can be seen that the lowest of satisfaction is $40 \%$.The highest of satisfaction is $95 \%$ from 2 respondents. The most of respondent in level $75 \%$ by 17 respondents.

\section{Factor Analysis of Service Quality}

Table-7 Factor of quality of service

\begin{tabular}{|l|c|c|c|c|}
\hline KMO $=0.893$ & & & & \\
\hline Anti image correlation $>0.3$ & $21.393 \%$ & $19.013 \%$ & $6.350 \%$ \\
\hline Variance value & $22.241 \%$ & $68.997 \%$ \\
\hline $\begin{array}{l}\text { Total Variance } \\
\text { value }\end{array}$ & Component-1 & Component-2 & Component-3 & Component-4 \\
\hline & $\mathrm{X} 7$ & $\mathrm{X} 5$ & $\mathrm{X} 1$ & X14 \\
\hline & $\mathrm{X} 10$ & $\mathrm{X} 6$ & $\mathrm{X} 2$ & X18 \\
\hline & $\mathrm{X} 11$ & $\mathrm{X} 8$ & $\mathrm{X} 3$ & \\
\hline & $\mathrm{X} 12$ & $\mathrm{X} 9$ & $\mathrm{X} 17$ & \\
\hline & $\mathrm{X} 13$ & $\mathrm{~T}$ & & \\
\hline & $\mathrm{X} 16$ & $\mathrm{X} 4$ and X15 not include in factor analysis \\
\hline
\end{tabular}

From table-2, show that average value of response between scale- 2 to scale- 3 . It is meant, as overall, most of respondent consider those variables as badly level to good enough level. The value of Kaiser Meyer Olkin (KMO) as 0.893. The value of Bartlett Test of Sphericity as 1169.130 at the of significant level 0.000. Diagonal value in Anti Image Correlation matrix is greater than 0.3. All of that, show that the data of 18 variables are adequate for factor computation. Based on the value of eigenvalue greater than 1 (one), there are 4 group of variables. Each group of variables has different value of variance as shown at table-7. Total variance expalined, as 68,997\%, which is indicate that the result of factor computation in satisfactory. For each component, the reduce variable as shown at table-8 and its interpretation.

Table-8 interpretation of service quality variables

\begin{tabular}{|c|c|}
\hline Variables & Interpretation \\
\hline $\begin{array}{l}\text { X7 - Comfortable at sitting in compartment } \\
\text { X10-Comfortable of Compartment Condition } \\
\text { X11-Temperature in Compartment /AC } \\
\text { X12 - Cleanness in Compartment } \\
\text { X13 - Fastness of service in Compartment } \\
\text { X16 - Security in Compartment }\end{array}$ & $\begin{array}{l}\text { The most responded at the first degree. It is meant, } \\
\text { those variables, as good enough variables at Argo } \\
\text { Parahyangan train service at the first degree. Those } \\
\text { group variables have quality at the first degree }\end{array}$ \\
\hline $\begin{array}{l}\text { X5 - Security at Station } \\
\text { X6 - Service at Waiting Room } \\
\text { X8 - To handle Shock Problem } \\
\text { X9 - To Handle the noise }\end{array}$ & $\begin{array}{l}\text { The second degree responded, It is meant, those } \\
\text { variables, as good enough variables at Argo } \\
\text { Parahyangan train service at the second degree. } \\
\text { Those group variables have quality at the second } \\
\text { degree }\end{array}$ \\
\hline $\begin{array}{l}\text { X1 - Accurateness of Time Travel } \\
\text { X2 - Frequency of Argo Parahyangan in a day } \\
\text { X3 - Service at Ticket Window } \\
\text { X17 - Menu in Compartment }\end{array}$ & $\begin{array}{l}\text { The third degree responded, It is meant, those } \\
\text { variables, as good enough variables at Argo } \\
\text { Parahyangan train service at the third degree. Those } \\
\text { group variables have quality at the third degree }\end{array}$ \\
\hline
\end{tabular}




\begin{tabular}{|llcl}
\hline $\begin{array}{l}\text { X14-Entertaintmen } \\
\text { Compartment } \\
\text { X18 - Expense }\end{array}$ & Facility TV / Music in & $\begin{array}{l}\text { The fourth degree responded, It is meant, those } \\
\text { variables, as a badly variables at Argo Parahyangan } \\
\text { train service at the fourth degree. Those group } \\
\text { variables have quality at the fourth degree. }\end{array}$ \\
\hline
\end{tabular}

\section{Factor Analysis Conclusion}

The degree of service quality will decrease from first degree to fourth degree, so that, X14 and X18 variables, which lie at fourth degree, are variables with the lowest degree of quality service variables compared to another degree. The highest degree of quality service variable lie in the first degree. Based on this, then for improving quality of service for Argo Parahyangan, PT.KAI management should increase and improvement to service quality variables by making priority as follow:

1. First priority are variables in the fourth degree or in component-4, those are:

- X14 - Entertainment facility /TV/Music in compartment

- X18 - Expense

2. Second priority are variables in the third degree or in component-3, those are:

- X1 - Accurateness of time travel

- X2 - Frequency of Argo Parahyangan in a day

- X3 - Service at ticket window

- X17 - Menu in compartment

3. Third priority are variables in the second degree or in component-2, those are:

- X5 - Security at station

- X6 - Service at waiting room

- $\mathrm{X} 8$ - To handle shock problem

- X9 - To handle the noise

4. Fourth priority are variables in the first degree or in component-1, those are:

- X7 - Comfortable sitting in compartment

- X10 - Comfortable in compartment condition

- X11 - Temperature in compartment/ AC

- X12 - Cleanness in compartment

- X13 - Fastness of service in compartment

- X16 - Security in compartment

\section{Mutiple regression analysis}

Multiple regression analysis will be used analyze the relation between level of satisfaction of Argo Parahyangan passenger with quality of service. In this case as dependent variable is level of satisfaction of Argo Parahyangan passenger which expressed in percentage, that filled by passenger. While as independent variables are 18 service quality variables. So that, the figure of multiple regression model will be analyzed, as implicit, as follow: Level of passenger satisfaction $=$ Function $(X 1, X 2, X 3, X 4, X 5, X 6, X 7, X 8, X 9, X 10$, $\mathrm{X} 11, \mathrm{X} 12, \mathrm{X} 13$, X14, X15, X16, X17, X18 )

The stepwise regression method used in computation. 
By notice at the average value, it can be seen that average value of passenger satisfaction level about $70 \%$. While the quality of service about scale-2 (badly) and scale-3 (good enough). Based on stepwise criteria, then we find the significant variable for construct the regression model as follow:

$$
\mathrm{Y}=\text { Function }(\mathrm{X} 12, \mathrm{X} 11, \mathrm{X} 3, \mathrm{X} 1)
$$

In this case the chosen variable for construct multiple regression model are X12, X11, X3 and X1. R-square value of regression is 0.480 ; it is meant $48 \%$ of satisfaction level of Argo Parahyangan passenger is determined by service quality level from variable X12, $\mathrm{X} 11, \mathrm{X} 3$ and X1. Standard error of regression is 10.24; this value is small enough, so, it can be said the regression model is fit to the data. Durbin Watson value as a computation result is 1.828 , greater than Durbin Watson upper (1.76); it is meant, in regression model there is no auto correlation. Based on above analysis, it can be said the model regression is a good model.The regression model have $\mathrm{F}$ computation is 21.926. The F-table is 2.76. Because F computation (21.926) is greater than F-table, so it is meant that variable X12, $\mathrm{X} 11, \mathrm{X} 3$ and $\mathrm{X} 1$ as together are significant influence to the level of satisfaction.

The objective of analysis of t-test for regression model is to test is each independent variable significant influence to dependent variable. From the computation, $\mathrm{t}$ computation for variable $\mathrm{X} 12, \mathrm{X} 11, \mathrm{X} 3$ and $\mathrm{X} 1$ are $3.852,2.579,2.235$ and 2.224 respectively. Because t-computation is greater than 2 (Hair), it can be concluded that each independent variable is significant influence to the dependent variable.

The regression model is:

Level of satisfaction $=15.684+5.594 \mathrm{X} 12+3.537 \mathrm{X} 11+3.540 \mathrm{X} 3+3.025 \mathrm{X}$

Whereas X12 is Cleanness in Compartment

$\mathrm{X} 11$ is Temperature in compartment / AC

$\mathrm{X} 3$ is service at ticket window

$\mathrm{X} 1$ is Accurateness of time travel

Variables X12, X11, X3 and X1 have the Beta value 0.350, $0.218,0.179$ and 0.191 respectively. Based on the Beta value, the $\mathrm{X} 12$ have the biggest contribution to the level of satisfaction. Variable $\mathrm{X} 11$ is the second contribution, Variable $\mathrm{X} 1$ is the third contribution, and then variable $\mathrm{X} 3$ is the fourth contribution to the dependent variable.

From the model we can find there are correlation between dependent variable and independent variable as follow:

1. Correlation between levels of satisfaction with X12- Cleanness in compartment, is 0.597

2. Correlation between level of satisfaction with X11 - Temperature in compartment /Ac is 0.488

3. Correlation between levels of satisfaction with X1 - Accurateness of time travel is 0.482

4. Correlation between levels of satisfaction with $\mathrm{X} 3$ - Service at ticket window, is 0.406 .

All correlations are significant.

Based on regression model, it can be concluded that:

1. Passenger satisfaction will be increase if his accurateness of time travel of Argo 
Parahyangan goes on to improve.

2. Passenger satisfaction will be increase if service at ticket window goes on to improve.

3. Passenger satisfaction will be increase if temperature in compartment goes on to maintain and to care the AC facility.

4. Passenger satisfaction will be increase if cleanness in compartment goes on to always clean.

\section{Implication for managerial action}

Based on the analysis, PT.KAI management should be done some strategy and priority how to improve the service quality at Argo Parahyangan train. The strategy to improve the passenger satisfaction is to improve the variables $\mathrm{X} 1, \mathrm{X} 3, \mathrm{X} 11$ and $\mathrm{X} 12$.

To improve the accurateness of time travel (X1), can be done by:

1. Controlling to the departure time

2. Controlling to the network schedule with another train

3. Controlling to the speed of train

4. Controlling to the preparing the compartment and locomotive before travelling

To improve the service at ticket counter (X3), can be done by:

1. Open the ticket window earlier before departure ( may be 1,5 - 2 hour before time departure)

2. To add the ticket counter

3. To improve the fastness of service at ticket counter

4. Ordering ticket by phone.

To improve the services at temperature in compartment (X11), it can be done by:

1. Always control and cheking the AC equipment

2. To on the AC before departure.

3. Always control to the temperature.

To improve the cleanness in compartment (X12), it can be done by:

1. To clean quickly the compartment as train is arrive

2. Controlling the cleaness in compartment in travelling

Beside improve those variables that significant influence to passenger satisfaction, PT.KAI management can make the priority of improving as we have mentioned in factor analysis.

\section{CONCLUSION AND RECOMMENDATION}

\section{Conclusion}

Some primry conclusion can be derived based on this research as follow:

1. The quality of service at Argo Parahyangan train is in range badly (scale-2) to good enough (scale-3). So that, the hyphothesis that have defined is not true.

2. The quality of service is not meeting the passenger expectation. The hyphotesis is not true. 
3. The level of passenger satisfaction (average) is $70,90 \%$. The hypothesis is proved.

4. Only 4 variables that significant influence to level of satisfaction. Those variable are :

- X1 - Accurateness of time travel

- X3 - Service at ticket window

- X11- Temperature in compartment

- X12- Cleanness in compartment

5. Based on conclusion number 3 , the hypothesis that quality service influence to passenger satisfaction is true.

Other conclusions are:

1. $35 \%$ of respondent are private employee

2. $33 \%$ of respondent are $\mathrm{S} 1$

3. $59 \%$ of respondent have income per month greater than 2 million rupiah

4. $91 \%$ of respondent using Argo Parahyangan in one -five times per month

5. $56 \%$ of respondent use Parahyangan Executive for another transportation.

6. $39 \%$ of respondent use Argo Parahyangan for another interest.

7. X12- Cleanness in compartment as a variable that have the highest contribution to the level of satisfaction.

8. X11- Temperature in compartment as a varibles that have the second contribution to the level of satisfaction

9. X3- Service at ticket window as a variable with the third contribution to the level of significant.

10. X1 - Accurateness of time travel as a variable with the forth contribution to the level of satisfaction

\section{Recommendation}

As recommendations based on this research are:

1. PT.KAI should improve the quality of service variable as the aim to improve the level of satisfaction of Argo Parahyangan train

2. Four variables of service $(\mathrm{X} 1, \mathrm{X} 3, \mathrm{X} 11$ and $\mathrm{X} 12$ ) become the main variables to be improved

3. In improving all variable in this research, can be used the priority scale that have discussed in factor analysis.

\section{Remark}

As a remark based on writer experience during this research for improving the research are:

1. Number of respondent can be added

2. The questionnaire should be delivered more one time shoot, and more one trip.

3. The questionnaire should be better is taken in different day in a week.

4. More variable can be added

5. The model of research can be expanded by using another multivariate technique. 


\section{REFERENCES}

Abadi Dwi Saputra, 2010, Analysis of Train Passenger Responses on Provided Service Case study: PT. Kereta Api Indonesia and Statens Järnvägar (SJ) AB,Sweden, Thesis, Service ScienceProgram Karlstad University Spring 2010

Adam, Ebert , 1995, Production And Operations Management, Prentice Hall, Singapore

Barry Render, 1997, Principles of Operations Management, Second Edition, Prentice Hall, New Jersey

Berkowitz, Eric N., Roger A. Kerin, William Rudelius, 1986, Marketing, St. Louis, Mosby College Publishing.

Chase, Aquilano, Jacobs, 1998, Production and Operations Management Manufacturing and Services , Eighth Edition, Mc. Graw Hill, New York, USA.

Corporate Plan Perumka, 1992- 1996

Dillon, William R and Mattew Goldstein,1984, Multivariate Analysis; Methods and Applications, New York, John Wiley.

Hair, Joseph F.JR, Anderson Rolph E,Tatham Ronald L, Black William , 1995, Multivariate Data Analysis With Reading, Prentice Hall, International Edition, New Jersey

Jan Hendrik Peters, 1999,Service Management, managing the image ,Trisakti University, Jakarta

Johnson Richard A, Wichern Dean W, 1992, Applied Multivariate Statistical Analysis, Prentice Hall, New Jersey

John E. Hanke, 1992, Business Forecasting, Fourth Edition, Allyn and Bacon, Boston

Khan Rubayet RAHAMAN And Md. Arifur RAHAMAN, 2009, Service Quality Attributes Affecting The Satisfaction of Railway Passengers of Selective Route in Southwestern Part of Bangladesh, Theoretical and Emperical Researches in Urban Management, Number 3 (12)/ August 2009

Kotler, Philip, 1994, Marketing Management, Eight edition, Prentice Hall, New Jersey

Montgomery Douglass C,1982, Introduction to Linear Regression Analysis, John Wiley \& Sons, New York 
Manheim, Marvin L., 1979, Fundamentals of Transportation System Analysis, vol.I: Basic Concept, Massachusetts, The MIT Press.

Nurosis, Marija J.,1993, SPSS for Windows Professionals Statistic Release 6.0, Chicago , SPSS Inc.

Sheeba. A. A and Dr. K. Kumuthadevi, 2013, Service Quality of South Indian RailwayDeterminants of Passenger Satisfaction in Trains., International Journal of Business and Management Invention ISSN (Online): 2319 - 8028, ISSN (Print): 2319 801X, www.ijbmi.org Volume 2 Issue 2 || February. 2013\| PP.49-54

Syed Muhammad Irfan, Daisy Mui Hung Kee and Saman Shahbaz, 2012, Service Quality and Rail Transport in Pakistan: A Passenger Perspective, World Applied Sciences Journal 18 (3): 361-369, 2012, ISSN 1818-4952, (C IDOSI Publications, 2012, DOI: 10.5829/idosi.wasj.2012.18.03.3044 